https://doi.org/10.37208/tgn27124

\section{The mayfly Baetis digitatus (Bengtsson, 1912) (Ephemeroptera: Baetidae) in Scotland}

\author{
C.R. Macadam ${ }^{1} \&$ A. Farr \\ ${ }^{1}$ Buglife - The Invertebrate Conservation Trust, \\ Balallan House, 24 Allan Park, Stirling FK8 2QG \\ E-mail: craig.macadam@buglife.org.uk
}

The scarce iron blue mayfly (Baetis digitatus Bengtsson, 1912) was first recorded in Great Britain from the East Stoke millstream on the River Frome in Dorset (MüllerLiebenau, 1969; Crisp \& Gledhill, 1970; Kimmins, 1972). Further records have been made since 1990 from Monmouthshire and Hampshire. However, there are historical records from Ceredigion, Powys, Devon, Hampshire and Herefordshire (Macadam, 2016). It was discovered in Scotland in the Lunan Burn near Blairgowrie in 1986 (Gunn \& Wright, 1994) and this has remained the only Scottish location for this species to date.

Nymphs of this species inhabit riffle areas of rivers and streams where they can typically be found crawling amongst macrophytes, although they will swim in short, darting bursts if disturbed (Macadam \& Bennett, 2010). There is one generation of this species per year, which overwinters as half-grown nymphs. There is little or no growth over the winter months with the remainder of their growth taking part in the spring (Söderström, 1991). The flight period extends from May to October (Elliott \& Humpesch, 1983), with recent work showing that there may be two distinct peaks in the flight period - one in the spring and another in the autumn (C. Macadam, pers. obs.). This suggests that there may be two separate cohorts: a slow growing winter cohort and a much faster growing summer cohort.

The Lunan Burn rises to the north of Dunkeld at an altitude of $352 \mathrm{~m}$ and flows east to south-easterly for approximately $24 \mathrm{~km}$ to its confluence with the River Isla west of Coupar Angus. During its course the watercourse flows through five large lochs: Loch of Craiglush, Loch of the Lowes, Butterstone Loch, Loch of Clunie, and Marlee Loch. These lochs form the Dunkeld-Blairgowrie Lochs Special Area of Conservation which is designated principally for their oligotrophic to mesotrophic nature (Anon., 2018). The upper catchment of the Lunan Burn comprises mainly commercial conifer plantations and below Butterstone Loch the land use changes to arable agriculture. In 201213 a pair of Eurasian beavers (Castor fiber) established a lodge on the Lunan Burn to the south-east of Marlee Loch. Beavers have since established a number of dams which are likely to alter the hydrology of the watercourse (Campbell et al., 2012).

The Lunan Burn immediately downstream of Marlee Loch (NO147433) was visited on 11th May 2018 to check the status of the population of Baetis digitatus. This river section was approximately $6 \mathrm{~m}$ wide with a water depth $0.2-0.4 \mathrm{~m}$ during the visit. The bed consisted predominantly of pebbles and the channel was heavily shaded by deciduous trees.

Samples of the freshwater macro-invertebrates were collected with a standard pond net $(0.25 \times 0.25 \mathrm{~m}$ frame, $1 \mathrm{~mm}$ net mesh). Numerous nymphs of Baetis digitatus were recorded, together with several adults, confirming the continued existence of the population discovered at this site in 1986. Further surveys are required to determine the extent of the population in the Lunan Burn catchment.

Two further Scottish populations of Baetis digitatus were discovered during surveys in Dumfries and Galloway in the Drumpail Burn upstream of Drumpail Bridge on the Glenluce to Tarf Bridge road on 16th July 2018, and in the Water of Malzie immediately downstream of Mochrum Loch (NX31015383) on 29th July 2018.

The Drumpail Burn rises on Artfield Fell at an altitude of $196 \mathrm{~m}$ above sea level, approximately $11 \mathrm{~km}$ north of Glenluce. It flows in a southerly direction before turning eastward to join the Tarf Water approximately $1 \mathrm{~km}$ south of Tarf Bridge. Baetis digitatus was found in a reach immediately upstream of the Drumpail Bridge on the Glenluce to Tarf Bridge road. The river here was approximately $1.5 \mathrm{~m}$ wide with a maximum depth of $0.3 \mathrm{~m}$. Flow in this section was relatively swift and there were a few submerged macrophytes present. The bed consisted of stones and small boulders and the watercourse had an open aspect as it flowed through open moorland with scattered scrub.

The Water of Malzie is formed from the outflows of several interconnected lochs including Mochrum Loch, Castle Loch, Black Loch, Fell Loch and Loch Hempton in the area of the Moor of Drumwalt. The source rises at an altitude of $110 \mathrm{~m}$ around $1 \mathrm{~km}$ from the shore of the Solway Firth at Luce Bay. It flows north-easterly for approximately $13 \mathrm{~km}$ to its confluence with the River Bladnoch, upstream of Bladnoch. Baetis digitatus was found in a reach of the Water of Malzie close to the Old Place of Mochrum. The stream at this point was approximately $2 \mathrm{~m}$ wide with a maximum depth of $0.5 \mathrm{~m}$. Flow in this section was slight and there were submerged and emergent macrophytes present. The bed consisted of organic material including peat and silt, with occasional pockets of small pebbles, and the banks were steep and faced with stonework. A number of bushes and small trees shaded parts of the watercourse, although the area where $B$. digitatus was collected had an open aspect. 
The discovery of new populations of $B$. digitatus in Scotland was predicted by Gunn \& Wright (1994). The similarities in habitat and appearance between nymphs and adults of $B$. digitatus and B. niger may have caused some past taxonomic confusion and the likelihood of further populations of $B$. digitatus being discovered in the future is high. Two of the known Scottish populations are found immediately downstream of the outflow of a loch, which suggests that it may be useful to search similar sites for this species.

\section{REFERENCES}

Anon. (2018). Dunkeld-Blairgowrie Lochs Special Area of Conservation. SAC Account at http://jncc.defra.gov.uk/ProtectedSites/SACselectio n/sac.asp?EUCode=UK0012638 Accessed 5th August 2018.

Campbell, R.D., Harrington, A., Ross, A. \& Harrington, L. (2012). Distribution, Population Assessment and Activities of Beavers in Tayside. Scottish Natural Heritage Commissioned Report No. 540.

Crisp, D.T. \& Gledhill, T. (1970). A quantitative description of the recovery of the bottom fauna in a muddy reach of a mill stream in southern England after draining and dredging. Archiv für Hydrobiologie 67, 502-541.

Elliott, J.M. \& Humpesch, U.H. (1983). A Key to the Adults of the British Ephemeroptera with Notes on their Ecology. Scientific Publications of the Freshwater Biological Association No. 47.

Gunn, R.J.M. \& Wright, J.F. (1994). Baetis digitatus Bengtsson (Ephemeroptera) new to Scotland with records from England and Wales. Entomologist's Monthly Magazine 130, 197-199.

Kimmins, D.E. (1972). A Revised Key to the Adults of the British species of Ephemeroptera with Notes on their Ecology. (2nd revised edition). Scientific Publications of the Freshwater Biological Association 15.

Macadam, C.R. (2016). A Review of the Mayflies (Ephemeroptera) of Great Britain. Species Status No. 28. Natural England Commissioned Report, NECR193.

Macadam, C.R. \& Bennett, C. (2010). A Pictorial Guide to British Ephemeroptera. Field Studies Council, Shrewsbury.

Müller-Liebenau, I. (1969). Revision der europäischen Arten der Gattung Baetis Leach, 1815 (Insecta, Ephemeroptera). Gewässer und Abwässer 48/49, 1214 https://doi.org/10.1002/mmnd.19810280102

Söderström, O. (1991). Life cycles and nymphal growth of twelve coexisting mayfly species in a boreal river. In: Alba-Tercedor, J. \& Sánchez-Ortega, A. (Editors). Overview and Strategies of Ephemeroptera and Plecoptera, pp. 503-514. Sandhill Crane Press, Gainesville, Florida. 